\title{
Ecosystem Indicators Development for Coho and Chinook Salmon
}

\author{
Kathryn Sobocinski ${ }^{1,2}$, Correigh Greene ${ }^{1}$, Neala Kendall ${ }^{3}$, Joe Anderson ${ }^{3}$, Mara Zimmerman ${ }^{3,4}$, and Michael \\ Schmidt $^{2}$ \\ ${ }^{I}$ National Oceanic and Atmospheric Administration, National Marine Fisheries Service, Northwest Fisheries \\ Science Center, 2725 Montlake Blvd. E., Seattle, WA 98112, USA \\ ${ }^{2}$ Long Live the Kings, 1326 5th Ave, \#450, Seattle, WA, 98101, USA \\ ${ }^{3}$ Washington Department of Fish and Wildlife, 1111 Washington St. SE, Olympia, WA 98501, USA \\ ${ }^{4}$ Current address: Coast Salmon Partnership, 100 South "I" Street, Suite 103, Aberdeen, WA 98520, USA
}

Keywords: Ecosystem, indicators, Pacific salmon, generalized additive models

Recent work on Chinook and coho salmon and steelhead trout has shown a decline in the marine survival of Salish Sea populations that was not evident in populations from coastal regions (Zimmerman et al. 2015; Ruff et al. 2017; Kendall et al. 2017). The causes of this decline in marine survival are likely complex, and may include bottom-up processes that drive prey availability, top-down processes, including increasing abundances of predators that may be exacerbating mortality, as well as a multitude of anthropogenic factors such as habitat loss, contaminants, and hatchery management practices that may contribute to disease, reduced fish condition, and ultimately increased mortality. The cumulative effects of these factors are unknown. Previous work showed that for Chinook, a single oceanographic climate index (North Pacific Gyre Oscillation) did not perform well in explaining survival patterns (Ruff et al. 2017). Recent work on the development of indicators of Puget Sound steelhead survival showed that predator abundance, patterns in hatchery releases, and timing of freshwater input, as well as oceanographic conditions, were informative in predicting marine survival (Sobocinski et al. in review). While the three species with observed declines in marine survival (Fig. 1) have different life-histories, and are therefore subjected to variable pressures at multiple scales, there are some commonalities in factors explaining marine survival over the 40-year time period from the late 1970s to present.

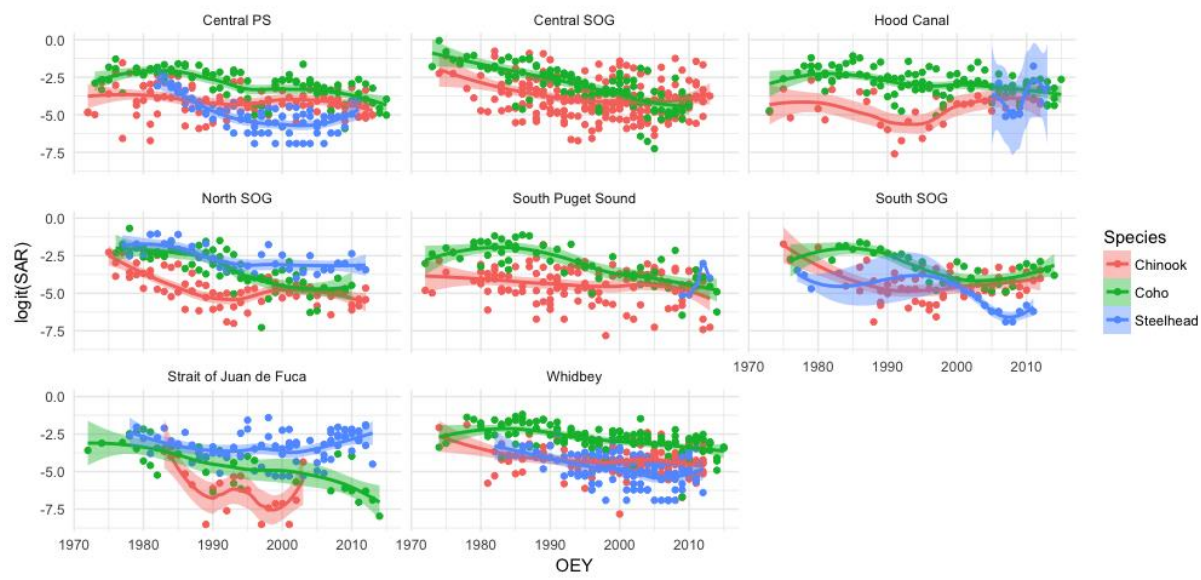

Fig. 1. Marine survival trends for three species of salmon across the subbasins of the Salish Sea, including Puget Sound (Central Puget Sound (PS), South Puget Sound, Whidbey, Hood Canal), the Strait of Juan de Fuca, and the Strait of Georgia (South Strait of Georgia (SOG), Central SOG and South SOG). Survival is shown as logit transformed smolt-to-adult return rates from the 1970s to 2015.

We developed hypotheses related to predation, competition, environmental variation, and anthropogenic impacts to frame our analysis and to identify a suite of factors that was best at explaining variation in survival time series for populations in Puget Sound, WA, USA. From these hypotheses, we generated time series of available and relevant data to use as indicators for each hypothesis (Table 1). We used generalized additive modeling to describe variation in survival with multiple covariates at ocean, regional, and local scales. We used smolt-to-adult return ratios (SAR) as the response variable; updates to the survival dataset using the methods of Ruff et al. (2017, Chinook) and Zimmerman et al. (2015, coho) allowed for analysis up through ocean entry year 2015. For each hypothesis we generated multiple generalized additive models and used best subsets model selection to identify the combination of indicators explaining the most variance in salmon marine survival.

All correspondence should be addressed to K. Sobocinski. 
Table 1. Hypotheses relating to Chinook and coho marine survival and indicators associated with each.

\begin{tabular}{|c|c|}
\hline HYPOTHESIS & INDICATORS \\
\hline \multirow{10}{*}{$\begin{array}{l}\text { H1: PREDATOR BUFFERING } \\
\text { (ABUNDANCE) }\end{array}$} & Seal Abundance \\
\hline & Orca Abundance \\
\hline & SOG Herring Abundance \\
\hline & PS Herring Spawning Stock Biomass \\
\hline & PS Pink Salmon Abundance (Outmigrating) \\
\hline & Fraser Pink Salmon Abundance (Outmigrating) \\
\hline & Yearling Chinook Hatchery Release Abundance \\
\hline & Subyearling Chinook Hatchery Release Abundance \\
\hline & Yearling Coho Hatchery Release Abundance \\
\hline & Index of Ocean Salmon \\
\hline \multirow[t]{7}{*}{ H2: PREDATOR BUFFERING (TIMING) } & Seal Abundance \\
\hline & Orca Abundance \\
\hline & Yearling Chinook Hatchery Release Date \\
\hline & Subyearling Chinook Hatchery Release Date \\
\hline & Yearling Coho Hatchery Release Date \\
\hline & Subyearling Coho Hatchery Release Date \\
\hline & CV of Subyearling Chinook Hatchery Release Date \\
\hline H3: FOOD AVAILABILITY AND & SST \\
\hline COMPETITION (DENSITY- & Salinity \\
\hline \multirow{15}{*}{ DEPENDENT) } & PS Herring Spawning Stock Biomass \\
\hline & PS Pink Salmon Abundance (Out) \\
\hline & Fraser Pink Salmon Abundance (Out) \\
\hline & Index of Ocean Salmon \\
\hline & Fraser River Flow (Spring) \\
\hline & PS River Flow (Apr.-May) \\
\hline & Chl $a$ (JDF Strait) \\
\hline & SOG Wind Index \\
\hline & Upwelling Index \\
\hline & Yearling Chinook Hatchery Release Abundance \\
\hline & Subyearling Chinook Hatchery Release Abundance \\
\hline & Yearling Coho Hatchery Release Abundance \\
\hline & Precipitation (Spring) \\
\hline & Stratification Index at Race Rocks \\
\hline & Max Air Temp (Spring) \\
\hline \multirow{9}{*}{$\begin{array}{l}\text { H4: FOOD AVAILABILITY TIMING } \\
\text { (DENSITY-INDEPENDENT) }\end{array}$} & Cumulative Degree Days \\
\hline & Date of $75 \%$ Cumulative Flow \\
\hline & Duration between $25 \%$ and $75 \%$ Cumulative Flow \\
\hline & Spring Transition Date \\
\hline & Yearling Chinook Hatchery Release Date \\
\hline & Subyearling Chinook Hatchery Release Date \\
\hline & Yearling Coho Hatchery Release Date \\
\hline & Subyearling Coho Hatchery Release Date \\
\hline & $\mathrm{CV}$ of Subyearling Chinook Hatchery Release Date \\
\hline \multirow[t]{12}{*}{ H5: WATER QUALITY } & SST \\
\hline & Salinity \\
\hline & River Flow (Spring) \\
\hline & Sea Level \\
\hline & Precipitation (Spring) \\
\hline & Stratification Index at Race Rocks \\
\hline & Max Air Temp (Spring) \\
\hline & SOG Wind Index \\
\hline & PDO \\
\hline & PNI \\
\hline & NPGO \\
\hline & NPI \\
\hline \multirow[t]{5}{*}{ H6: WATER DELIVERY TIMING } & Cumulative Degree Days \\
\hline & Date of $75 \%$ Cumulative Flow \\
\hline & Duration between $25 \%$ and $75 \%$ Cumulative Flow \\
\hline & Date of Max. Freshwater Flow \\
\hline & Spring Transition Date \\
\hline \multirow[t]{6}{*}{ H7: ANTHROPOGENIC IMPACTS } & Population \\
\hline & Yearling Chinook Hatchery Release Abundance \\
\hline & Subyearling Chinook Hatchery Release Abundance \\
\hline & Yearling Coho Hatchery Release Abundance \\
\hline & Coho/Chinook Harvest \\
\hline & Total Salmon Harvest \\
\hline
\end{tabular}

In general, hypotheses related to freshwater delivery performed poorly, while those related to predation, competition, and water quality explained more variance (30-40\% for the best models). For Chinook, the factors with strongest support included sea surface temperature in Puget Sound, spring river flow in Puget Sound, seal abundance, subyearling Chinook hatchery release date, and yearling coho hatchery release date. For all except water temperature, the relationship between marine survival and the indicator was negative. For coho, the variables with 
the most support included North Pacific Index in the summer (negative relationship with SAR), spring precipitation (negative relationship with SAR), stratification in the Strait of Juan de Fuca (parabolic relationship), the CV of Chinook subyearling hatchery release date (positive relationship with SAR, where the greater the variation in release date, the higher survival is), maximum spring temperature (negative relationship with SAR), seal abundance (negative relationship with SAR), summer NPGO (positive relationship with SAR), and Strait of Georgia herring abundance (positive relationship with SAR). These variables collectively hint at numerous causes of decreased survival for all three species of interest, from unfavorable ocean conditions, to increased predation and prey

limitation. Lack of data for some potentially important ecological variables (for example, young of the year forage fishes in Puget Sound) may limit the explanatory power of our models related to marine survival.

\section{REFERENCES}

Kendall, N.W., G.W. Marston, and M.M. Klungle. 2017. Declining patterns of Pacific Northwest steelhead trout (Oncorhynchus mykiss) adult abundance and smolt survival in the ocean. Can. J. Fish. Aquat. Sci. 74: 12751290.

Ruff, C.P., J.H. Anderson, I.M. Kemp, N.W. Kendall, P. Mchugh, L.Vélez-Espino, C.M. Greene, M. Trudel, C.A. Holt, K.E. Ryding, and K. Rawson. 2017. Salish Sea Chinook salmon exhibit weaker coherence in early marine survival trends than coastal populations. Fish. Oceanogr. doi:10.1111/fog.12222.

Sobocinski, K.L., N.W. Kendall, C.M. Greene, and M. Schmidt. In review. Ecosystem indicators of marine survival in Puget Sound steelhead trout. Prog. Oceanogr.

Zimmerman, M., J.R. Irvine, M. O'Neill, J.H. Anderson, C.G. Greene, J. Weinheimer, M. Trudel, and K. Rawson. 2015. Spatial and temporal patterns in smolt survival of wild and hatchery coho salmon in the Salish Sea. Mar. Coast. Fish. 7: 116-134. 